Andrei L. Kindzelskii • Imran Amhad • Donald Keller •

M.-J. Zhou • Richard P. Haugland •

B. A. Garni-Wagner - Margaret R. Gyetko •

Robert F. Todd - Howard R. Petty

\title{
Pericellular proteolysis by leukocytes and tumor cells on substrates: focal activation and the role of urokinase-type plasminogen activator
}

Accepted: 3 March 2004 / Published online: 20 March 2004

(C) Springer-Verlag 2004

\begin{abstract}
Previous studies have shown that the urokinase-type plasminogen activator receptor (UPAR) is localized to the adherence sites of leukocytes and tumor cells suggesting that pericellular proteolysis may accompany focal activation of adherence. To assess for focused pericellular proteolytic activity, we prepared two-dimensional substrates coated with FITC-casein or Bodipy FLBSA. These molecules are poorly fluorescent, but become highly fluorescent after proteolytic degradation. Fluorescent peptide products were observed at adherence sites of stationary human neutrophils and at lamellipodia of polarized neutrophils. During cell migration, multiple regions of proteolysis appeared sequentially beneath the cell. Similarly, proteolytic action was restricted to adherence sites of resting HT1080 tumor cells but localized to the invadopodia of active cells. Using an extracellular fluorescence quenching method, we demonstrate that these fluorescent peptide products are extracellular. The uPA/uPAR system played an important role in the observed proteolytic activation. Plasminogen activator inhibitor-1 significantly reduced focal proteolysis. Sites of
\end{abstract}

A. L. Kindzelskii · I. Amhad · D. Keller · H. R. Petty $(\square)$

Department of Ophthalmology and Visual Sciences

and Microbiology and Immunology,

University of Michigan Medical School,

Ann Arbor, Michigan, 48105, USA

e-mail: hpetty@umich.edu

Tel.: +1-734-6470384

Fax: +1-734-9363815

M.-J. Zhou · R. P. Haugland

Molecular Probes,

Eugene, Oregon, USA

B. A. Garni-Wagner · R. F. Todd III

Hematology/Oncology Division, Department of Internal Medicine, University of Michigan Medical School,

Michigan, USA

M. R. Gyetko

Pulmonary and Critical Care Division,

Ann Arbor Veterans Affairs Medical Center

and University of Michigan Medical School,

Michigan, USA focal proteolysis matched the membrane distribution of uPAR. When uPA was dissociated from uPAR by acid washing, substantially reduced pericellular proteolysis was found. uPAR-negative T47D tumor cells did not express significant levels of substrate proteolysis. However, transfectant clones expressing uPAR (for example, T47D-26) displayed high levels of fluorescence indicating proteolysis at adherence sites. To provide further evidence for the role of the UPA/uPAR system in pericellular proteolysis, peritoneal macrophages from uPA knock-out (uPA-l-) and control (uPA+/+) mice were studied. Pericellular proteolysis was dramatically reduced in uPAnegative peritoneal macrophages. Thus, we have: (1) developed a novel methodology to detect pericellular proteolytic function, (2) demonstrated focused activation of proteolytic enzymatic activity in several cell types, (3) demonstrated its usefulness in real-time studies of cell migration, and (4) showed that the uPA/uPAR system is an important contributor to focal pericellular proteolysis.

Keywords Neutrophils · Tumor cells · Adhesion · Proteolysis · Plasminogen activator

\section{Introduction}

Cell migration is required for normal physiological functions such as host defense, embryogenesis, and angiogenesis, and for the deleterious invasive and metastatic programs of malignant cells. Migration within and between tissue planes involves a complex series of events including cytoskeletal reorganization, shape change, and adhesion/detachment cycles (Springer 1990). One factor that may affect cell migration in vivo is pericellular proteolysis. Pericellular proteolysis of extracellular materials and basement membranes is mediated by several extracellular and membrane-associated proteolytic enzymes. One enzyme system believed to play a key role in pericellular proteolysis is the urokinase-type plasminogen activator (uPA) and its substrate plasminogen (Saksela and Rifkin 1988; Blasi 1993). Leukocytes and tumor cells 
can synthesize and secrete uPA (Vassalli et al. 1976; Granelli-Piperno et al. 1977). Secreted uPA then binds to high affinity cell surface receptors (uPAR) also expressed on invasive cells such as leukocytes and tumor cells (Ploug et al. 1991), where it catalyzes proteolysis including the conversion of the zymogen plasminogen to plasmin. Plasmin has a very broad substrate specificity including fibrin, basement membrane components, and other latent enzymes including procollagenases. This enzyme cascade thus promotes pericellular proteolysis and, in turn, the migration of cells in complex matrix environments.

Several lines of evidence support the functional importance of the uPA/uPAR system in cell trafficking and clinical disease. First, uPAR expression correlates with the ability of leukocytes to invade tissues (Kirchheimer and Remold 1989). Interestingly, increased production of uPA has been associated with increased severity of arthritis (Kummer et al. 1992). Second, the aggressiveness of several cancers has been linked to the level of urokinase-type plasminogen activator receptor (uPAR) expression; high levels of uPAR expression correlate with a poor prognosis (Bianchi et al. 1994; Fazioli and Blasi 1994). Furthermore, Crowley et al. (1993) have shown that metastasis of human PC3 prostate carcinoma cells in a nude mouse model can be prevented by blockade of uPAR. This clinical relationship has been more fully developed at the molecular/cellular level. Inhibition of uPA reduced metastatic potential (Ossowski and Reich 1983; Hearing et al. 1988; Ossowski et al. 1991). On the other hand, increased uPA levels promote tumor invasiveness and metastasis in vivo (see, for example, Blasi 1993). Therefore, it seems likely that heightened UPAR expression and UPA activity enhances cell surface proteolytic activity thereby enhancing cell invasion and metastasis.

We have previously demonstrated that certain GPIlinked membrane proteins physically and functionally interact with integrins (see, for example, Petty and Todd 1996). We were the first to demonstrate that the $\beta 2$ integrin complement receptor type 3 (CR3) physically interacts with uPAR (Xue et al. 1994). Subsequently, we and others have provided both physical and functional evidence for $\beta 2$ integrin-uPAR interactions (Gyetko et al. 1994; Xue et al. 1994; Bohuslav et al. 1995; Cao et al. 1995; Simon et al. 1996; Sitrin et al. 1996). Similarly, we and others have recently shown that other integrin families of tumor cells interact with uPAR (Wei et al. 1996; Xue et al. 1997). Thus, adherence proteins and uPAR, which play complementary roles in cell migration, are physically and phenomenologically coupled with one another.

Since integrins preferentially accumulate at adherence sites and lamellipodia (Petty 1993; Kindzelskii et al. 1997), integrin-to-uPAR interactions may thus account for the ability of UPAR to accumulate at adherence sites (Pollanen et al. 1987, 1988; Herbert and Baker 1988; Takahashi et al. 1990) and lamellipodia (Estreicher et al. 1990; Kindzelskii et al. 1996a). However, the structural localization of uPAR does not necessarily identify sites of pericellular proteolysis. To define the nature of pericellular proteolysis, we have developed microscopic assays to detect pericellular proteolysis. These assays utilize fluorescent probes that are highly quenched when bound to intact proteins, but become highly fluorescent when exposed to protease activity. We have found that pericellular proteolytic activity is not uniformly distributed about cells, but rather is found at specific sites; these sites also contain significant amounts of UPAR.

\section{Materials and methods}

Materials

Proteinase K was obtained from Sigma (St. Louis, MO). FITCcasein and Bodipy FL-BSA were obtained from Molecular Probes (Eugene, OR).

Human neutrophils

Heparinized venous blood collected from healthy volunteers was mixed 1:1 with $0.9 \%$ saline and separated from mononuclear cells by Ficoll-Hypaque density gradient centrifugation. Neutrophils were then isolated by sedimentation in 5\% dextran $/ 0.9 \%$ saline (Sigma), and the erythrocytes removed by hypotonic lysis. After washing with RPMI 1640 (Gibco, Grand Island, NY) supplemented with penicillin $(100 \mathrm{U} / \mathrm{ml})$, streptomycin $(100 \mathrm{mg} / \mathrm{ml})$, gentamicin (100 mg/ml), L-glutamine ( $2 \mathrm{mM})$, and $10 \%$ fetal bovine serum (Hyclone, Logan, UT), cells were taken for experimentation.

\section{Tumor cell lines}

HT1080 cells were grown as adherent cells using DMEM medium (Gibco) containing 10\% fetal calf serum, $200 \mathrm{mM}$ L-glutamine (Gibco), and $100 \mu \mathrm{g} / \mathrm{ml}$ gentamicin. T47D cells were grown in RPMI 1640 containing $10 \%$ fetal calf serum, $100 \mu \mathrm{g} / \mathrm{ml}$ gentamicin, and $0.2 \mathrm{IU}$ insulin $/ \mathrm{ml}$. Both cell lines were grown in a humidified $\mathrm{CO}_{2}$ incubator at $37^{\circ} \mathrm{C}$. Trypsin/EDTA (Gibco) was added to cells for approximately $5 \mathrm{~min}$ to dislodge cells from the substrate. Trypsin inhibitor was then added to block further enzyme action. Cells were plated on culture dishes or incubated on coverslips overnight.

\section{Transfections}

T47D cells were obtained from the American Type Culture Collection (ATCC, Rockville, MD). These cells were transfected to express uPAR (CD87; clone T47D-26) by the calcium phosphate method as previously reported (Cao et al. 1995). Cells were cotransfected with $1.5 \mu \mathrm{g}$ cDNA encoding pSV2gpt (Mulligan and Berg 1981) and $15 \mu \mathrm{g}$ cDNA encoding uPAR (Min et al. 1992). Colonies that grew in HXM selection medium (DMEM) containing $10 \%$ calf serum, $50 \mathrm{U} / \mathrm{ml}$ penicillin, $50 \mathrm{mg} / \mathrm{ml}$ streptomycin, $15 \mathrm{mg} /$ $\mathrm{ml}$ hypoxanthine, $250 \mathrm{mg} / \mathrm{ml}$ xanthine, and $25 \mathrm{mg} / \mathrm{ml}$ mycophenolic acid, with $\mathrm{pH}$ adjusted to 7.2-7.3, were screened for expression of uPAR by indirect immunofluorescence flow cytometry.

Monoclonal antibodies (mAbs) and immunofluorescence flow cytometry

Anti-uPAR [clone 3B10, anti-Mo3f (CD87)] was obtained as described (Min et al. 1992). Saturating quantities of this mAb were employed in indirect immunofluorescence analysis UPAR expres- 
sion in comparison to background staining using isotype-matched negative control mAb, using a Coulter EPICS Elite flow cytometer (Coulter, Hialeah, FL) as described (Mizukami et al. 1991a). For the immunofluorescence labeling experiments shown below, $\mathrm{F}\left(\mathrm{ab}^{\prime}\right)_{2}$ fragments of anti-CD87 mAb were conjugated with TRITC as described (Kindzelskii et al. 1996a). These findings were confirmed using a rabbit polyclonal anti-uPAR antibody (Mizukami et al. 1991b; data not shown).

\section{Confirmation of uPAR expression by T47D cells}

UPAR expression on T47D cells isolated from the transfection protocol were studied by flow cytometry using anti-uPAR mAb (clone 3B10) as were two other anti-uPAR mAbs VIM5 (Gadd et al. 1990; Todd et al. 1995) and M9 (Nash et al. 1989; Todd et al. 1995) (data not shown). T47D-wt (not shown) and T47D-5 N (exposed to the spNeo resistance gene alone) did not express uPAR whereas substantial amounts of uPAR were expressed by T47D-15, T47D-17, T47D-25, and T47D-26 transfectants. Phorbol myristate acetate (PMA)-treated (19 nM for $24 \mathrm{~h}$ ) U937 cells were used as positive controls (data not shown). An isotype-matched irrelevant $\mathrm{mAb}$ was used for negative controls. Similar results were obtained using mAbs VIM5 and M9 and with FITC-uPA $(0.125 \mu \mathrm{g} /$ $2.5 \times 10^{5}$ cells) (data not shown). Thus, the phenotypes of the transfectants have been confirmed.

\section{Animals}

Transgenic uPA-depleted mice (uPA-/-) and background-matched control mice $(\mathrm{uPA}+/+)$ were generous gifts from Dr. Peter Carmeliet (Carmeliet et al. 1994). Mice were housed in pathogen-free rooms in the University of Michigan Department of Laboratory Animal Medicine, which is fully accredited by the American Association for Accreditation of Laboratory Animal Care. This study was approved by the University of Michigan Committee on Use and Care of Animals (UCUCA). Mice were periodically checked for murine hepatitis virus and were found to be negative, and were fed standard animal chow and chlorinated tap water ad libitum. The genotype of the uPA-/- and uPA $+/+$ mice was confirmed by polymerase chain reaction analysis. Mice were used at $8-12$ weeks of age.

Preparation of peritoneal macrophages from uPA-Iand $\mathrm{uPA}+/+$ mice

The uPA-/- and uPA+/+ mice were euthanized by $\mathrm{CO}_{2}$ inhalation. The peritoneal cavity was lavaged with $20 \mathrm{ml}$ PBS containing EDTA $(5 \mathrm{mM})$. After centrifugation and washing, the cells were resuspended in RPMI 1640 (Gibco) supplemented with penicillin $(100 \mathrm{U} / \mathrm{ml})$, streptomycin $(100 \mathrm{mg} / \mathrm{ml})$, gentamicin $(100 \mathrm{mg} / \mathrm{ml})$, L-glutamine ( $2 \mathrm{mM})$, and $10 \%$ fetal bovine serum (Hyclone). The cells from each animal were kept separate.

Procedures for enzymatic fluorescence microscopy

\section{FITC-casein procedure for intensified microscopy}

Two milligrams of FITC-casein was dissolved in $200 \mu \mathrm{l}$ DMSO. After vortexing, a working solution was prepared by mixing $10 \mu \mathrm{l}$ of this solution with $190 \mu \mathrm{l}$ distilled water. Five microliters of this solution was mixed with $145 \mu$ l distilled water. In a separate test tube, $3 \mathrm{mg}$ BSA were dissolved in $300 \mu$ l distilled water. One hundred and fifty microliters of the BSA solution was mixed with the diluted casein/water solution, and $40 \mu \mathrm{l}$ of the casein-BSA mixture was pipetted onto acetone-cleaned coverslips. The coverslips were placed into a covered petri dish and then incubated at $37^{\circ} \mathrm{C}$ for $1 \mathrm{~h}$. The coverslips were removed and washed gently with Hanks' buffered saline solution (HBSS) prior to experiments.

\section{Bodipy FL-BSA overnight incubation protocol}

Slides were prepared by dissolving Bodipy FL conjugate $(6 \%$; Molecular Probes), BSA (10\%; Sigma), and human fibrinogen (10\%; Calbiochem, La Jolla, CA) in water. In some experiments human plasminogen activator inhibitor-1 (PAI-1) was added $5 \mathrm{ng} /$ ml (American Diagnostica, Greenwich, CT). This solution was evenly coated onto glass slides using a glass rod. The coated slides were incubated for $2 \mathrm{~h}$ at $37^{\circ} \mathrm{C}$ in a humidified chamber. Following incubation the slides were dipped in HBSS. All cells were prestimulated with PMA $(10 \mathrm{ng} / \mathrm{ml})$ for $2 \mathrm{~h}$ at $37^{\circ} \mathrm{C}$. The cell suspensions were then layered on top of the coated slides and allowed to adhere for $30 \mathrm{~min}$ at $37^{\circ} \mathrm{C}$ in a humidified box. The slides were dipped in HBSS to remove non-adherent cells, coverslips were added, and samples were returned to the humidified box and incubated at $37^{\circ} \mathrm{C}$ for $8-16 \mathrm{~h}$. Where indicated PAI-1 $(5 \mathrm{ng} / \mathrm{ml})$ was added to the cell suspension mixture immediately prior to layering the cells onto the coated slides.

\section{Bodipy FL-BSA procedures for intensified microscopy}

BSA $(50 \mu \mathrm{g})$ and Bodipy FL-BSA $(30 \mu \mathrm{g})$ were dissolved in $20 \mu \mathrm{l}$ DMSO. After suspension in solvent, the entire solution volume was diluted to $0.5 \mathrm{ml}$; this stock solution could be stored for up to 1 week at $4^{\circ} \mathrm{C}$. In procedure A, $100 \mu \mathrm{l}$ of the stock solution was evenly coated onto acetone-cleaned glass surfaces using a glass rod. The coverslip was incubated for $2 \mathrm{~h}$ at $37^{\circ} \mathrm{C}$ in a humid air atmosphere under a petri dish (but not allowed to dry). The coverslip was gently washed with HBSS. In procedure B, the stock solution was diluted 1:10 with distilled deionized water and passed through a $0.2-\mu \mathrm{m}$ filter. Coverslips were coated with an even layer of this solution, which was allowed to dry under a hood. The coverslip was gently washed with HBSS. These coated substrates are used for experiments. Samples were then incubated for various periods of time at $37^{\circ} \mathrm{C}$.

\section{Intensified microscopy}

Cells were observed using an Axiovert inverted fluorescence microscope (Zeiss, New York, NY) with mercury illumination interfaced to a Perceptics (Knoxville, TN) Biovision image processing system. A long-pass dichroic mirror of $510 \mathrm{~nm}$ and a narrow bandpass discriminating filter (DF) set (Omega Optical, Brattleboro, VT) was used (excitation at $485 \mathrm{~nm}$ with a $22 \mathrm{~nm}$ bandpass and emission at $530 \mathrm{~nm}$ with a $30 \mathrm{~nm}$ bandpass) for FITC and Bodipy FL. TRITC fluorescence was detected using a $540 \mathrm{~nm}$ filter with a $20 \mathrm{~nm}$ bandpass and a $590 \mathrm{~nm}$ filter with a $30 \mathrm{~nm}$ bandpass in conjunction with a $560 \mathrm{~nm}$ dichroic mirror. The fluorescence images were collected with an intensified chargecoupled device camera (Geniisys; Dage-MTI, Michigan City, IN) (Kindzelskii et al. 1996a, b). DIC photomicrographs were taken using Zeiss polarizers and a charge-coupled device camera (model 72; Dage-MTI). To distinguish extracellular from intracellular fluorescence, samples were stained with $0.5 \mathrm{mg} / \mathrm{ml}$ crystal violet as previously described (Hed 1977; Krause et al. 1994).

\section{Single cell microspectrophotometry}

Single cell excitation spectra were recorded using a Photon Technology Intl. System (Monmouth Jct., NJ) as described (Artym and Petty 2002). A $510 \mathrm{~nm}$ long-pass dichroic mirror and an emission filter at $530 / 30 \mathrm{~nm}$ was employed. Single cell emission microspectrophotometry was performed using an imaging spectrophotometer, as described (Artym and Petty 2002). For emission spectrophotometry, cells were illuminated using an optical filter at 485DF22 $\mathrm{nm}$ and a 510lp dichroic mirror. 
Statistics

Comparisons between groups were performed using an unpaired Student's $t$-test (Zar 1984). Data are expressed as mean $\pm S E M ; n$ is the number of cells evaluated. All experiments were repeated on at least three independent occasions.

\section{Results}

Physical basis of enzymatic detection

To detect cell surface proteolytic function, we have developed a microscopic method wherein the emission intensity of surface-adsorbed labels is increased upon proteolytic disruption. Previous workers (Twinning 1984; Hormer and Beighton 1990; Farmer and Yuan 1991) have shown that the acquisition of an enhanced fluorescence signal is a sensitive biochemical assay for proteolytic activity. In this study we have employed two fluorescent labels to detect protease action: FITC-casein and Bodipy FL-BSA. Figure 1A shows the fluorescence emission spectra of a solution of FITC-casein in the presence and absence of proteinase $\mathrm{K}$ treatment $(5 \mathrm{U} / \mathrm{ml}$ for $60 \mathrm{~min}$ at $37^{\circ} \mathrm{C}$ ). The fluorescence of FITC-casein was strongly quenched in its native state. However, proteolysis of FITC-casein led to greatly enhanced levels of fluorescence. Figure 1B shows an identical experiment employing Bodipy FL-BSA. This reagent also showed a large protease-dependent increase in fluorescence emission. Furthermore, as can be seen by inspecting the control traces without protease addition, the signal-to-noise ratio was greater for Bodipy FL-BSA than FITC-casein. Both FITC-casein and Bodipy FL-BSA exhibited broad proteolytic sensitivities (Twinning 1984; Hormer and Beighton 1990; Farmer and Yuan 1991; Kindzelskii et al. 1998). However, the increase in sample fluorescence was not a general property of disrupted fluorescent proteins. Figure 1C shows FITC-conjugated BSA with and without treatment using proteinase $\mathrm{K}\left(5 \mathrm{U} / \mathrm{ml}\right.$ for $60 \mathrm{~min}$ at $\left.37^{\circ} \mathrm{C}\right)$. In this case, the fluorescence intensity was enhanced by only approximately $20 \%$. Thus, the changes in fluorescence quenching upon proteolysis are not a general property of fluorescent protein conjugates, but depends upon the proteins and dyes employed.

We next prepared surfaces containing FITC-casein or Bodipy FL-BSA. It is possible that a small proportion of the conjugates retained substantial fluorescence emission and that these conjugates formed clusters on the coverslip and that cells attached to these sites. To exclude this possibility, Bodipy FL-BSA-coated coverslips were imaged by fluorescence microscopy. A random pattern of dim fluorescence emission was observed with no bright areas of fluorescence intensity (data not shown). Furthermore, bright regions of fluorescence were not found in the background of the micrographs of cells shown below. We therefore used these surfaces to detect proteolytic action at the basal cell surface, which is reported as an increase in fluorescence intensity.

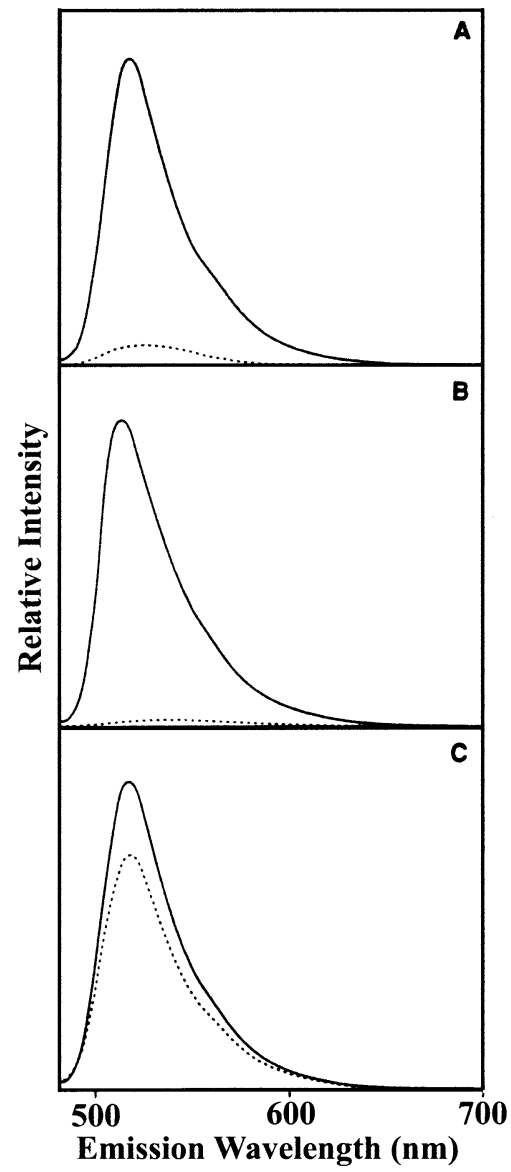

Fig. 1A-C Effect of proteolysis on the fluorescence emission spectra of FITC-casein (A), Bodipy FL-BSA (B), and FITC-BSA (C). The fluorescence intensity (ordinate) is plotted against the emission wavelength $(\mathrm{nm})$ (abscissa). Fluorophore-conjugated proteins were incubated with proteinase $\mathrm{K}$ at $5 \mathrm{U} / \mathrm{ml}$ for $60 \mathrm{~min}$ at $37^{\circ} \mathrm{C}$ (solid line) or in the absence of enzyme (dotted line). Proteolytic degradation relieves the self-quenching of fluorescence of FITC-casein (A) and Bodipy FL-BSA (B). However, this is not a general property of these compounds since the emission spectrum of FITC-BSA is not dramatically affected by proteolytic degradation $(\mathbf{C})$

Neutrophil-mediated pericellular proteolysis

Neutrophils were placed on FITC-casein or Bodipy FLBSA coated surfaces. In the first series of experiments neutrophils were washed to remove non-adherent serum components, suspended in HBSS, and then transferred to FITC-casein-coated glass coverslips. Adherent neutrophils showed enhanced proteolytic function in circular zones at adherence sites (Fig. 2B), consistent with integrin-to-uPAR interactions (Kindzelskii et al. 1996a). In contrast, polarized cells showed enhanced proteolytic action at the lamellipodium (Fig. 2D), which is consistent with the membrane distribution of UPAR on migrating neutrophils (Estreicher et al. 1990). To confirm the fact that sites of lamellipodial proteolysis correspond to sites of UPAR accumulation, we next performed double-labeling experiments using FITC-casein and TRITC-anti- 


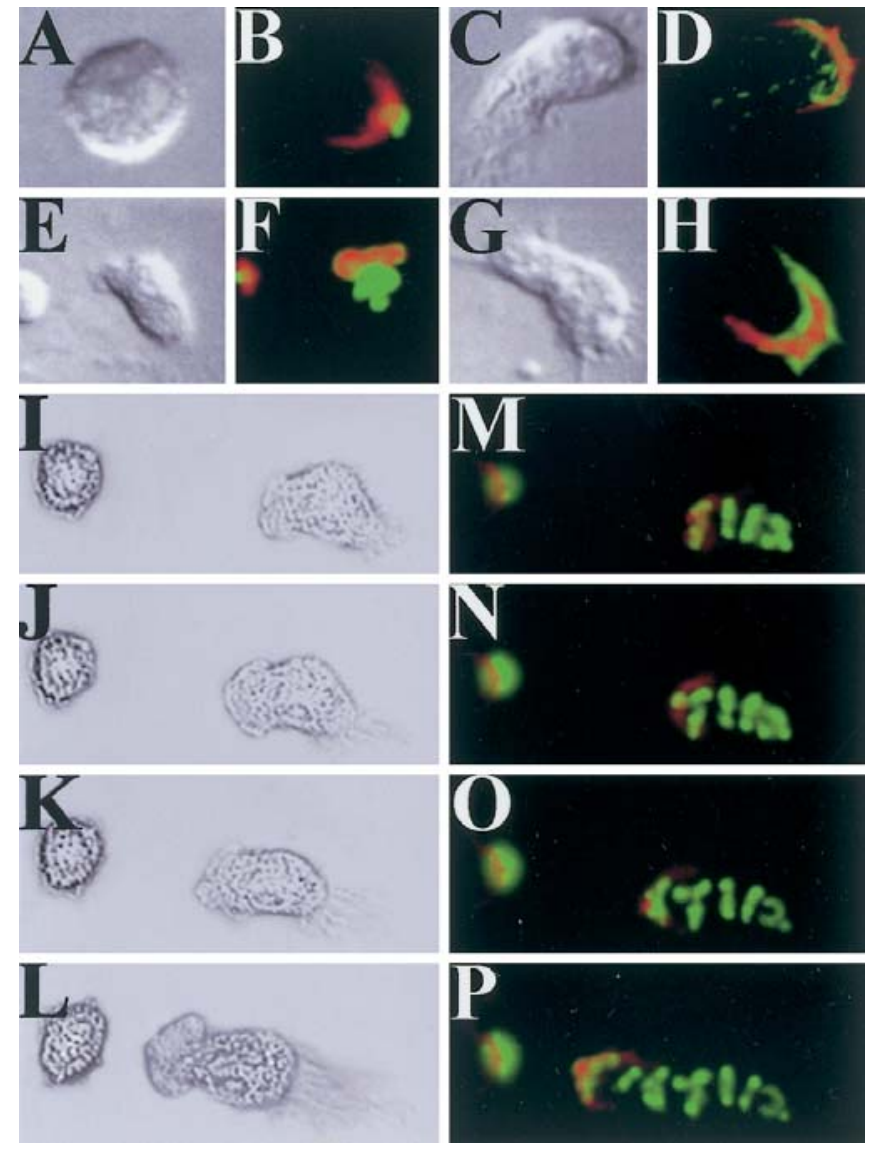

Fig. 2A-P Neutrophil-mediated pericellular proteolysis on surfaces. Surfaces were coated with a thin layer of dim FITC-casein (A-D) or Bodipy FL-BSA (E-H, M-P). Adherent and polarized cells are shown after $15-30$ min incubation at $37^{\circ} \mathrm{C}$ using DIC or fluorescence microscopy. Proteolytic activation causes an increase in fluorescence emission (green). Urokinase-type plasminogen activator receptor (UPAR) localization is shown in red. The adherent cells show zones of local proteolytic activity $(\mathbf{B}, \mathbf{F})$, which presumably corresponds to the region of cell attachment. In contrast, polarized cells show stripes at the leading edge $(\mathbf{D}, \mathbf{H})$. During these conditions, the uPAR signal (B, D, F, H: red $)$ substantially overlaps that of proteolysis (green). I to $\mathbf{P}$ illustrate the effect of cell movement on substrate proteolysis. Note the dynamic changes in surface proteolysis over time. This series of images was acquired in approximately $2 \mathrm{~min}$. A-H $\times 940 ; \mathbf{I}-\mathbf{P} \times 760$

uPAR-F $\left(\mathrm{ab}^{\prime}\right)_{2}$ fragments to assess uPAR distribution and proteolytic function. Figure $2 \mathrm{~B}, \mathrm{D}$ shows that UPAR and proteolytic activity co-localize beneath adherent cells and to the lamellipodia of polarized cells.

A similar series of experiments were conducted using substrates coated with Bodipy FL-BSA. Neutrophils adherent to Bodipy FL-BSA-coated substrates were analyzed by fluorescence microscopy. Regions of pericellular proteolysis were observed on stationary cells (Fig. 2F) whereas stripes of pericellular proteolysis were found at the lamellipodium of polarized neutrophils (Fig. 2H). Double-labeling experiments using Bodipy FL-BSA and TRITC-anti-uPAR-F $\left(\mathrm{ab}^{\prime}\right)_{2}$ fragments demonstrated that uPAR co-localized with sites of Bodipy FLBSA disruption (Fig. 2F, H). Interestingly, if cells were incubated at $37^{\circ} \mathrm{C}$ for longer periods of time, multiple linear regions ("stripes") of pericellular fluorescence can be observed for polarized cells (Fig. 2I-L and M-P), which is likely due to multiple contacts of the lamellipodium with the substrate. In this experiment a time series of images were collected using DIC and fluorescence microscopy. The round, stationary cell has one site of associated proteolytic activity. The morphologically polarized cell moves across the field of view. A series of proteolytic zones or stripes are observed. These likely correspond to regions where the lamellipodium has touched the substrate during migration. However, as time passes the earlier stripes become somewhat dimmer, which is likely due to the diffusion of the cleaved peptides away from the site of their formation. Thus, two independent reagents support the interpretation that cellassociated patterns of pericellular proteolysis can be observed and these patterns are time-dependent. Furthermore, the dequenching of Bodipy FL-BSA could not be accounted for by the production of reactive oxygen metabolites since chronic granulomatous disease neutrophils, which cannot undergo a respiratory burst, exhibited proteolytic responses indistinguishable from normal neutrophils (Kindzelskii et al. 1998). Therefore, reactive oxygen metabolites did not play a significant role in acquisition of the fluorescence signal. This is also consistent with the fact that oxidants can decrease the intensity of fluorochromes due to oxidative decomposition (Hafeman et al. 1984). Thus, the studies of Fig. 2 provide a microscopic assay for substrate proteolysis and direct evidence that pericellular proteolysis is not uniform about the perimeter of a cell, but rather is highly localized depending upon cell function.

Proteolytic activity is extracellular and sensitive to $\mathrm{pH}$

Inasmuch as neutrophils are phagocytic cells, it is possible that they might remove Bodipy FL-BSA from the substrate and then digest it within phagolysomes. We therefore sought to determine if the fluorescent products of Bodipy FL-BSA were internal or external. To do this, extracellular fluorescence was quenched using crystal violet (Hed 1977; Krause et al. 1994). Although extracellular fluorescence is quenched, intracellular fluorescence is not affected. Figure $3 \mathrm{~A}$ shows pericellular fluorescence emission spectra from a representative cell before and after addition of crystal violet. The single cell fluorescence emission spectrum of pericellular Bodipy FL products is shown. However, in the presence of crystal violet the spectrum is extensively quenched (Fig. 3A dotted line). To better characterize the mechanism of fluorescence quenching, single cell excitation spectra were recorded in the presence and absence of crystal violet (Fig. 3B). The spectra are averages of 50 separately acquired excitation spectra of pericellular fluorescence. The excitation peak is found at $485 \mathrm{~nm}$ in the presence and absence of crystal violet. However, the excitation at $485 \mathrm{~nm}$ is reduced while that at $410 \mathrm{~nm}$ is enhanced by 


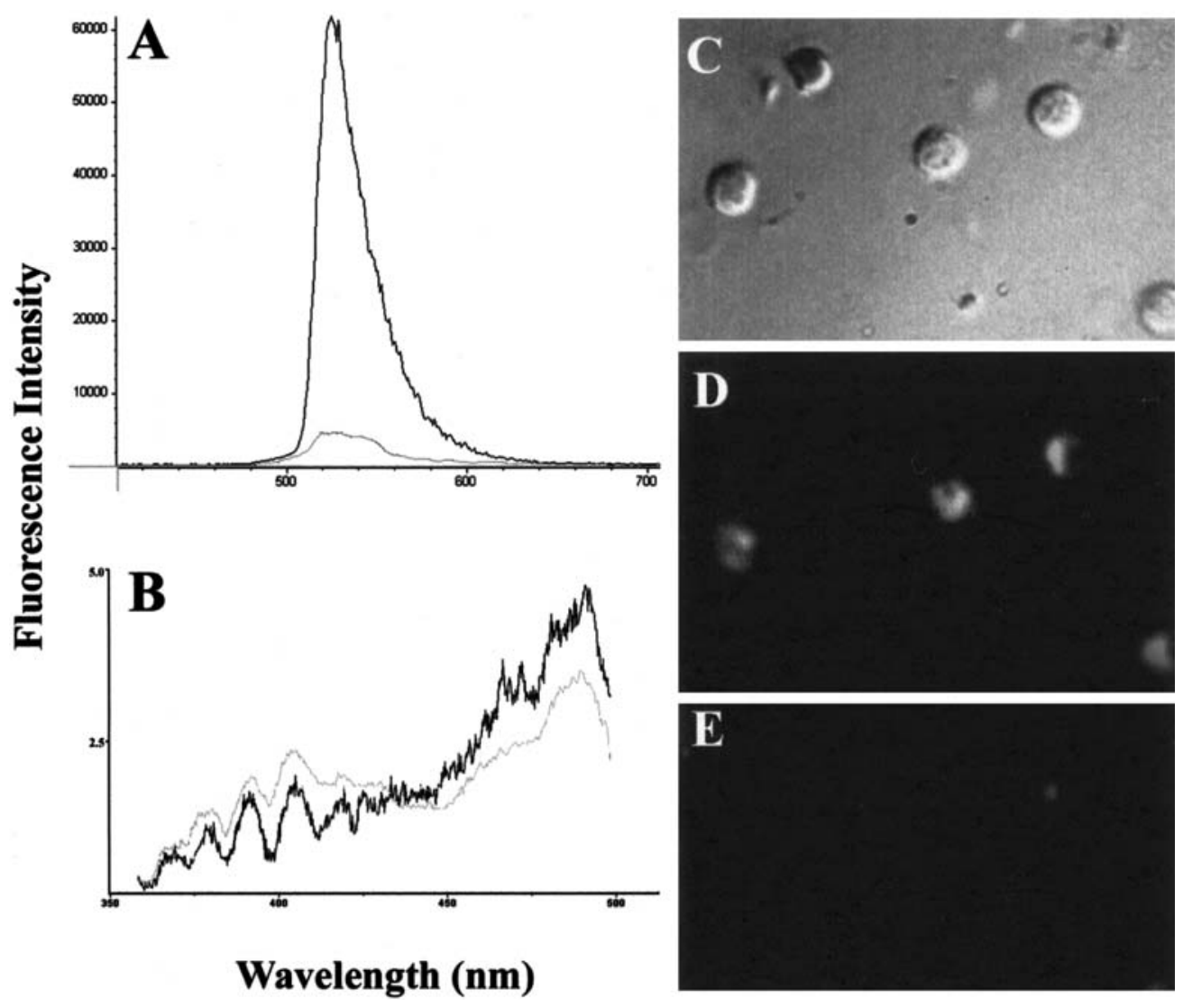

Fig. 3A-E Effect of crystal violet quenching on pericellular fluorescence. Neutrophils were incubated with Bodipy FL-BSAcoated surfaces for $15 \mathrm{~min}$ at $37^{\circ} \mathrm{C}$ and then observed by optical microscopy or microspectrophotometry. A Emission spectra of a representative single cell before (solid line) and after (dotted line) addition of crystal violet. A dramatic reduction in the emission at $520 \mathrm{~nm}$ is observed. Excitation spectra of pericellular proteolytic sites in the absence (solid line) and presence (dotted line) of crystal violet are shown in B. Fifty excitation scans were averaged for each

crystal violet. These changes in the excitation spectrum suggest that crystal violet can associate with Bodipy FL to mediate static quenching (Lakowicz 1983). In Fig. 3C-E, optical micrographs of cells before and after addition of crystal violet are shown. The reduced fluorescence in Fig. 3E versus Fig. 3D further demonstrates that the fluorescence label is extracellular. These differences were also quantitatively confirmed using microscopic photometry. Photon count rates of $161 \pm 32$ kilocounts/s (with a background of $17 \pm 10$ kilocounts/s) and $33 \pm 11$ kilocounts/s (with a background of $30 \pm 15$ kilocounts/s) were obtained in the absence and presence of crystal violet, respectively, for this cell population. Thus, most or all of the fluorescent products of Bodipy FL-BSA are extracellular.

We verified that conditions known to influence cell surface proteolysis and UPA expression also influence the fluorescence of Bodipy FL-BSA-coated surfaces. uPARbound UPA generates the active protease plasmin from its inactive precursor plasminogen (Saksela and Rifkin 1988). In the absence of Bodipy FL-BSA, the fluores- spectrum. Although the spectra are similar, changes can be noted in the regions near 485 and $410 \mathrm{~nm}$. C-E Three micrographs of the same field of cells. C DIC micrograph. Fluorescence micrographs are given in $\mathbf{D}$ and $\mathbf{E}$, which illustrate the pericellular proteolytic fragments detected before and after addition of crystal violet. The ability of crystal violet to quench this fluorescence indicates that the fluorescent peptides are on the exterior of the cells (Hed 1977). C-E $\times 740$

Table 1 Fluorescence intensity measurements of acid-treated cells

\begin{tabular}{lllll}
\hline FL-BSA & Serum & Acid & Time & Intensity (kilocount/s) \\
\hline- & - & - & 20 & $5.2 \pm 5.2$ \\
+ & - & - & 20 & $311 \pm 59$ \\
+ & + & - & 20 & $602 \pm 73 *$ \\
+ & - & - & 30 & $442 \pm 68$ \\
+ & - & + & 30 & $59 \pm 38^{* *}$ \\
+ & + & + & 30 & $264 \pm 98$ \\
\hline
\end{tabular}

$* P<0.001$ in comparison to the preceding line without serum plus FL-BSA

$* * P<0.01$ in comparison to the preceding line without acid washing

cence intensity of attached cells was minimal (Table 1). The cell-associated fluorescence signal of Bodipy FLBSA was significantly enhanced $(P<0.001)$ in the presence of serum in comparison to the absence of serum under otherwise identical conditions (Table 1). uPA can be stripped from cells using acid washing procedures (see, for example, Bajpai and Baker 1985). In the absence of both serum and acid washing, a fluorescence intensity of 
$442 \pm 68$ kilocounts/s was obtained after $30 \mathrm{~min}$ at $37^{\circ} \mathrm{C}$. Acid washing and in the absence of serum, dramatically reduced the fluorescence intensity relative to untreated samples (Table 1). However, when serum was added back to this sample, the fluorescence intensity was increased. Thus, conditions that augment pericellular proteolysis enhance Bodipy FL-BSA fluorescence whereas treatments that reduce uPA expression decrease Bodipy FLBSA fluorescence (Fig. 4A-H). This confirms the concept that Bodipy FL-BSA monitors pericellular proteolysis on surfaces.

Pericellular proteolysis by neutrophils is sensitive to PAI-1 inhibition

To determine whether the presence of plasminogen activator enzyme activity was required for pericellular cleavage of Bodipy FL-BSA and the generation of a fluorescence signal, the following experiments were done. Normal human neutrophils were activated with PMA for $2 \mathrm{~h}$ to increase uPA activity (Gyetko et al. 1988). Onehalf of the cells were permitted to adhere to Bodipy FLBSA-coated slides and incubated at $37^{\circ} \mathrm{C}$ for $8-16 \mathrm{~h}$ to allow proteolytic cleavage of the conjugate. The fluorescence intensity generated by these cells was compared to the intensity generated by neutrophils pretreated with human PAI-1, and allowed to adhere to PAI-1 containingBodipy FL-BSA. PAI-1 is a specific, naturally occurring, irreversible plasminogen activator inhibitor (Saksela and Rifkin 1988). Figure 4I shows adherent neutrophils under brightfield microscopy. Figure 4J shows the same low power field under fluorescence microscopy. Numerous bright areas of fluorescence surround the neutrophils, thus indicating the proteolytic cleavage of the Bodipy FL-BSA substrate. Figure 4K shows PAI-1 exposed neutrophils under brightfield microscopy. In Fig. 4L these cells are viewed under fluorescence conditions. The degree of fluorescence intensity is diminished in the PAI-1 treated neutrophils compared to neutrophils adhered to Bodipy FL-BSA in the absence of PAI-1.

These photographs were digitized, and the fluorescence intensity semiquantitatively expressed in arbitrary units. The intensity of the PAI-1-treated neutrophils was $15 \pm 3.4$ compared to $49.4 \pm 3.7$ for control neutrophils $(P<0.001)$. Thus, plasminogen activators substantially contribute to the cleavage of the Bodipy FL-BSA conjugate.

Pericellular proteolysis by $\mathrm{uPA}+/+$

and $\mathrm{UPA}-/-$ peritoneal macrophages

Whereas the inhibitory effect of PAI-1 on neutrophilmediated proteolysis of Bodipy FL-BSA supports the role of the plasminogen activator system, we sought to further document the specific involvement of uPA in pericellular proteolysis. To evaluate this, we compared resident peritoneal macrophages from transgenic uPA-deficient mice
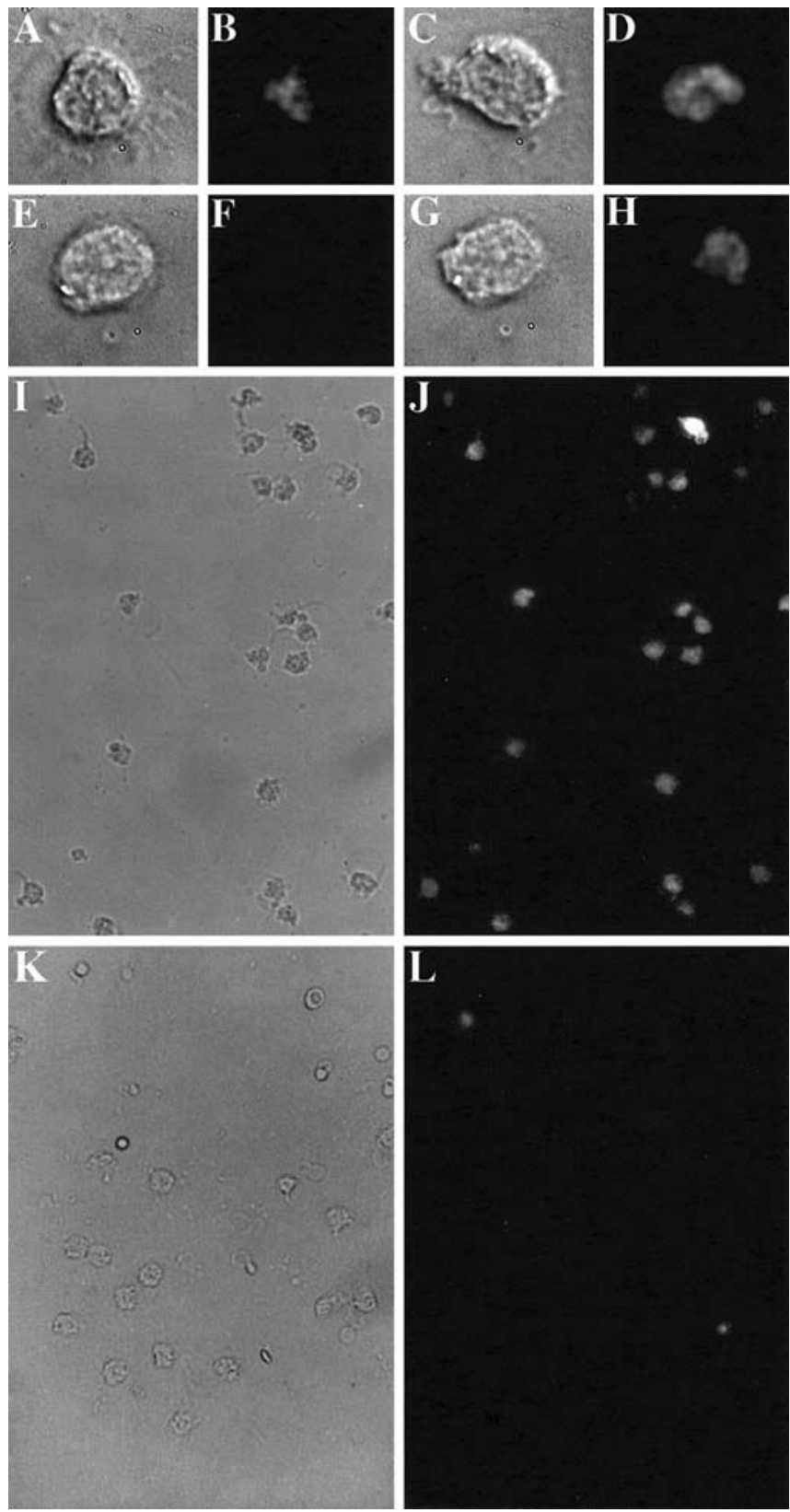

Fig. 4A-L Effect of acid stripping on and PAI-1 on the pericellular fluorescence of neutrophils. Brightfield $(\mathbf{A}, \mathbf{C}, \mathbf{E}, \mathbf{G}, \mathbf{I}, \mathbf{K})$ and fluorescence $(\mathbf{B}, \mathbf{D}, \mathbf{F}, \mathbf{H}, \mathbf{J}, \mathbf{L})$ micrographs are shown. Neutrophils were incubated with Bodipy FL-BSA-coated surfaces for 15 min at $37^{\circ} \mathrm{C}$ and then observed by optical microscopy. In the absence of acid stripping, a substantial amount of Bodipy FL-BSA degradation products are seen in the absence and presence of added serum (B and $\mathbf{D}$, respectively). However, the acid stripping procedure greatly reduces pericellular proteolytic activity $(\mathbf{F})$, which can be restored by adding serum $(\mathbf{H})$. To compare pericellular proteolysis in the presence and absence of PAI-1, PMA-treated neutrophils were permitted to adhere to Bodipy FL-BSA-coated slides in the absence and presence of PAI-1, and incubated at $37^{\circ} \mathrm{C}$ for $8-16 \mathrm{~h}$. I, J Adherent neutrophils in the absence of exogenous PAI-1. K, L PAI-1-treated cells adhered to PAI-1 containing Bodipy FL-BSAcoated surfaces. Acid stripping and PAI-1 dramatically reduce pericellular fluorescence. A-H ×960; I-L ×430 

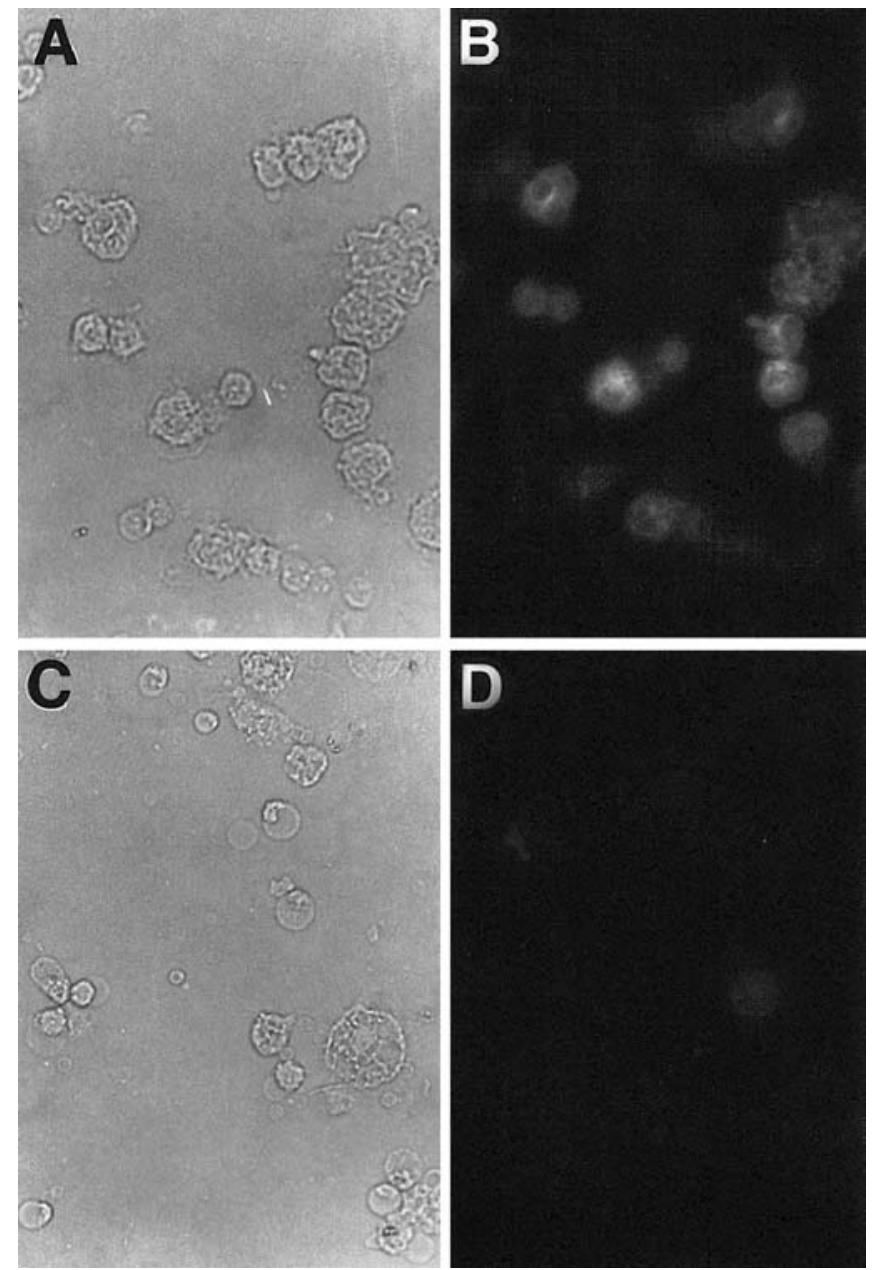

Fig. 5A-D Comparison of pericellular proteolysis by $u P A+/+$ and uPA-/- peritoneal macrophages. The resident peritoneal macrophages from the uPA+/+ and uPA-/- mice were allowed to adhere to Bodipy FL-BSA-coated slides and incubated at $37^{\circ} \mathrm{C}$ to allow proteolytic cleavage of the conjugate. A Adherent uPA+/+ peritoneal macrophages viewed by brightfield microscopy. B Same cells viewed under fluorescence microscopy. C Peritoneal macrophages from uPA-/- mice adhered to the Bodipy FL-BSA slides viewed under brightfield microscopy. D Same cells under fluorescence microscopy. $\times 540$

with cells from uPA-replete control mice. The uPAdeficient mice do not express UPA on the mRNA, protein, or activity levels (Carmeliet et al. 1994). The peritoneal macrophages from the uPA-/- and $\mathrm{uPA}+/+$ mice were allowed to adhere to the Bodipy FL-BSA-coated slides as described above. Non-adherent cells were washed off and the adherent cells were incubated overnight at $37^{\circ} \mathrm{C}$. The following day the pericellular fluorescence intensity was determined by fluorescence microscopy. Figure $5 \mathrm{~A}$ shows adherent $\mathrm{uPA}+/+$ peritoneal macrophages viewed by brightfield microscopy. Figure $5 \mathrm{~B}$ is a fluorescence photomicrograph of the same cells showing bright pericellular fluorescence indicative of cleavage of the Bodipy FL-BSA substrate. Figure 5C shows peritoneal macrophages from uPA-/- mice adherent to Bodipy FL-BSAcoated surfaces viewed by brightfield microscopy. Fig-
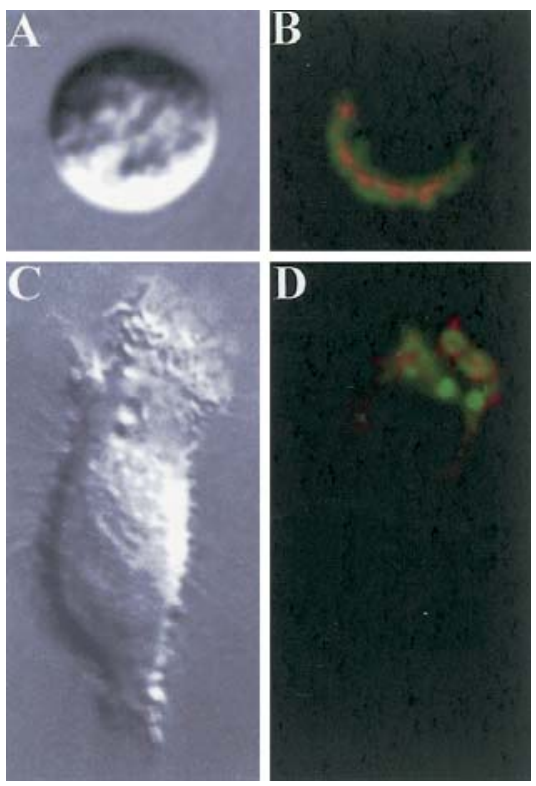

Fig. 6A-D Proteolytic activity associated with HT1080 cells. Cells were placed on Bodipy FL-BSA-coated surfaces (procedure B) and then observed on a $37^{\circ} \mathrm{C}$ microscope stage within $30 \mathrm{~min}$. DIC (A, C) and fluorescence (B, D) micrographs are shown. Focused pericellular proteolytic activity is noted on both spherical $(\mathbf{A}, \mathbf{B})$ and morphologically polarized (C, D) tumor cells. DIC (A) and fluorescence micrographs of UPAR (B) and the fluorescence of proteolytic products of Bodipy FL-BSA $(\mathbf{C})$ are shown. Note the similarity of these fluorescence images, suggesting colocalization of uPAR and proteolytic activity. Note that the invadopodium (D) of the polarized HT1080 cell is rich in proteolytic activity. Proteolytic activity associated with uPAR-enriched membrane regions of HT1080 cells. A, B $\times 1,000 ; \mathbf{C}, \mathbf{D} \times 1,200$

ure 5D shows these same cells under fluorescence microscopy. The degree of fluorescence surrounding the peritoneal macrophages from uPA-/- mice is much less than that seen by the uPA+/+ peritoneal macrophages. By image analysis the peritoneal macrophages from the uPA $+/+$ mice had $70.5 \pm 7.2$ units of intensity compared to $12.3 \pm 4.6$ units of intensity from the uPA-/- mice $(P<0.001)$. Since the deletion of uPA in these knockout mice is specific and tPA production and expression is unaltered (Carmeliet et al. 1994), we conclude that uPA substantially contributes to the cleavage of Bodipy FLBSA.

\section{Tumor cell-mediated pericellular proteolysis}

To confirm that pericellular proteolysis is not restricted to neutrophils in this system, we tested HT1080 fibrosarcoma cells. In the first series of experiments HT1080 cells were placed on Bodipy FL-BSA-coated glass coverslips. Spherical HT1080 (Fig. 6A) cells displayed regions of pericellular proteolytic activity (Fig. 6C). Figure 6B shows a double-labeling [Bodipy FL-BSA and TRITCanti-uPAR-F $\left(\mathrm{ab}^{\prime}\right)_{2}$ fragments] study of HT1080 cells. This experiment illustrates the co-localization of UPAR and local proteolysis. Figure 6C, D shows a polarized tumor 

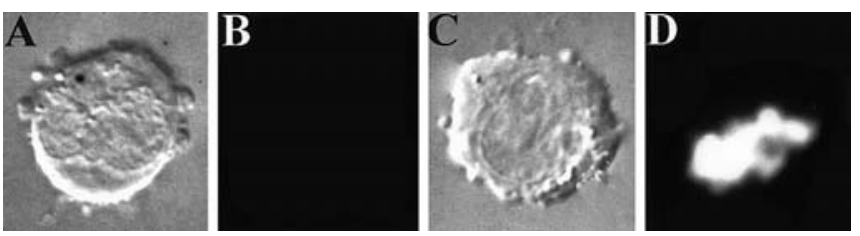

Fig. 7A-D Proteolytic activity associated with T47D-wt cells (A, B) and T47D-26 cells $(\mathbf{C}, \mathbf{D})$ associated with Bodipy FL-BSAcoated substrates (procedure A). DIC (A, C) and fluorescence (B, D) micrographs are shown. The gain of the camera and image processing procedures were identical in all micrographs, which were collected within 30 min during incubation at $37^{\circ} \mathrm{C}$. Cells not expressing the UPAR gene product did not give rise to pericellular proteolysis (B) whereas the transfectant expressing the uPAR gene generated large amounts of fluorescence $(\mathbf{D})$. All cell lines were capable of secreting the ligand uPA. $\times 1,700$

cell. Note that the invadopodium structure, which is rich in microvilli, possesses associated proteolytic activity. Thus, the leading edge of tumor cells is rich in proteolytic activity, as is the lamellipodium of polarized neutrophils (Fig. 2).

To illustrate the applicability of our results to additional cell types and to provide further data on the association of UPAR with pericellular proteolysis, we have carried out experiments using T47D breast cancer cells and uPAR transfectants of T47D cells. Flow cytometric studies characterized the expression of UPAR by these lines. For example, T47D cells did not express uPAR whereas T47D-26 cells did express uPAR. These cells were then allowed to attach to Bodipy FL-BSA-coated surfaces. Representative results are shown in Fig. 7. Although the parent cell line T47D did not express uPAR nor significant levels of pericellular proteolysis, the transfected T47D cell line expressing UPAR exhibited pericellular proteolysis. Thus, uPAR expression is an important contributor to the focused pericellular proteolysis in this system.

\section{Discussion}

This study provides direct experimental evidence that pericellular proteolysis is not uniform about the periphery of a cell, but rather is focused at specific sites in a uPA/ uPAR-dependent manner. These observations have been confirmed using two types of proteolytic indicators and hematopoietic and non-hematopoietic cell types. The nonuniformity in proteolytic activation is evident in the punctate substrate fluorescence found for stationary cells and the lamellipodial-related fluorescence of polarized neutrophils. Furthermore, the distribution of pericellular proteolytic activity is coincident with the distribution of UPAR, requires UPA, and is substantially affected by the expression of uPAR. Thus, we suggest that cells can spatially regulate the nature of pericellular proteolysis.

\section{Microscopic detection of proteolysis}

Previous workers have reported microscopic tools to detect pericellular proteolysis which employ negative staining techniques. Campbell and Campbell (1988) have reported an immunolabeling strategy to detect substrateassociated fibronectin degradation wherein degraded fibronectin loses its capacity to bind a fluorescently tagged anti-fibronectin antibody. Furthermore, disruption of surface-associated TRITC-fibronectin (Liou and Campbell 1996) or FITC-gelatin (Mueller et al. 1992; Coopman et al. 1996) leads to loss of pericellular fluorescence near cells. Although these techniques are suitable to detect pericellular proteolysis, they are limited in sensitivity. The dequenching approach provides an approach (Kindzelskii et al. 1998; Sameni et al. 2000) to enhance sensitivity. This increase in sensitivity permits real-time microscopic evaluation of pericellular proteolytic activity in living cells.

The method reported relies upon a chromophoreprotein conjugate in which the fluorescence intensity of the chromophore is highly quenched by nearby amino acids or other chromophores within the native protein structure (Figs. 1, 3). When these chromophore-protein conjugates are degraded by the action of proteases, the fluorescence intensity of their fragments is dramatically increased. This approach has been useful in sensitive biochemical evaluations of proteolytic activity (Twinning 1984; Hormer and Beighton 1990; Farmer and Yuan 1991). By adsorbing these molecules to surfaces, we have been able to spatially characterize the functional enzymatic character of pericellular proteolysis by living neutrophils and tumor cells using fluorescence microscopy (see, for example, Figs. 2, 5). In addition, Bodipy FLBSA can be used in conjunction with longer-term assays of proteolytic action (Figs. 4I-L, 7). The use of a positivestaining protocol has several inherent interpretative advantages. Proteolytic products do not rapidly diffuse away from the sample. Also, accessibility issues regarding the basal cell surface are also avoided since second-step reagents such as fluorescent antibodies are not employed. Moreover, as neutrophils and tumor cells can produce substantial quantities of oxidants (Babior 1978; Szatrowski and Nathan 1991) and since oxidants can chemically promote degradation of fluorochromes independent of proteolysis (Hafeman et al. 1984), the positive-staining protocol may more accurately reflect proteolytic action than negative staining where oxidants may artificially decrease the fluorescence intensity.

Two independent probes, FITC-casein and Bodipy FL-BSA were employed. Although either probe can be employed, Bodipy FL-BSA has several advantages. As shown by the emission spectra in Fig. 1, Bodipy FL-BSA has a better signal-to-noise ratio than FITC-casein; this likely improves the contrast of the micrographs. Moreover, FITC is more sensitive than Bodipy FL-BSA to photobleaching during illumination. Both probes have a broad substrate specificity (Twinning 1984; Hormer and Beighton 1990; Farmer and Yuan 1991; Kindzelskii et al. 
1998). FITC-casein forms flocs in aqueous solution. Consequently, organic solvents are necessary to obtain uniformly coated substrates. Floc formation also limits its ability to be used in gel matrices. These are not problems with Bodipy FL-BSA since it readily dissolves in aqueous solution. Thus, Bodipy FL-BSA possesses several advantages in the study of pericellular proteolysis.

Role of uPA/uPAR system

in focused pericellular proteolysis

Previous studies have shown that uPA and/or uPAR can be found at focal contacts of resting cells (Pollanen et al. 1987, 1988; Herbert and Baker 1988; Takahashi et al. 1990) or at lamellipodia of migrating cells (Estreicher et al. 1990; Kindzelskii et al. 1996a). The ability of cells to direct UPA and uPAR to specific sites raises the hypothesis that proteolytic function might also accumulate at specific sites. Although it is often suggested that sites of uPA accumulation are sites of enhanced proteolytic action (see, for example, Estreicher et al. 1990), this assumption has not been rigorously tested. There could be many other proteases associated with the cell surface; thus, uPAR redistribution might have little net effect on proteolytic function in other regions of a plasma membrane. Furthermore, uPA could catalyze the formation of plasmin which might then diffuse from this site and/or bind to distant plasmin receptors or the plasmin-bound plasmin receptors themselves could diffuse away from this site. Thus, we have used a fluorescence microscopic enzymatic technique to assess proteolytic action in parallel with assessment of uPAR distribution.

We have shown that pericellular proteolytic function is localized at specific sites of cell adherence for neutrophils and tumor cells. During neutrophil migration cell surface proteolytic function was primarily associated with the lamellipodium of cells, consistent with previous studies on UPA and UPAR distribution (Estreicher et al. 1990; Kindzelskii et al. 1996a). The focusing of proteolytic activity at adherence sites and lamellipodia may be accounted for by the spatial redistribution of uPAR molecules within the plasma membrane of leukocytes (Kindzelskii et al. 1997; Xue et al. 1997). Several independent lines of evidence suggest that the uPA/uPAR system plays an important role in mediating the pericellular proteolytic action observed in the present study. First, using double-labeling fluorescence microscopy, the spatial distribution of UPAR on neutrophil and tumor cell membranes was found to coincide with the pattern of pericellular proteolysis. The cell line T47D, which expresses low levels of uPAR, does not display significant levels of pericellular proteolytic activity. However, transfection of the uPAR gene into this parental cell line greatly heightens uPAR expression and pericellular proteolysis. Thus, in our systems the level of uPAR expression correlates with the level of pericellular proteolysis. On the other hand, factors that reduce the level of uPA and/or uPAR expression reduce pericellular proteolysis.
Removal of uPA from the cell surface by acid stripping reduced the fluorescence intensity observed in the presence of cells. Similarly, enzymatic inhibition with PAI-1 reduced pericellular proteolysis. Using peritoneal macrophages from uPA-knockout mice, a dramatic reduction in pericellular proteolysis was noted in comparison to uPA+/ + animals. By using multiple cell types and multiple confirmatory strategies, we minimize the possibility that some unknown extraneous factor acting in parallel with these methods (such as a contaminant in the PAI-1 sample or another gene perturbed by the transfection protocol) might have influenced the findings. Therefore, we suggest that the UPA/uPAR system plays an important role in the local generation of pericellular proteolysis observed in neutrophils and tumor cells, although other downstream substrata of plasmin could also contribute.

Since uPAR is a GPI-linked membrane protein, what tethers it to specific adherence sites and lamellipodia? We and others have previously shown that multiple integrin families can physically associate with uPAR (Gyetko et al. 1994; Xue et al. 1994, 1997; Bohuslav et al. 1995; Cao et al. 1995; Petty and Todd 1996; Simon et al. 1996; Sitrin et al. 1996; Wei et al. 1996; Kindzelskii et al. 1997). Thus, cytoskeletally associated integrin molecules may tether UPAR to adherence sites and lamellipodia where uPA-charged UPAR can initiate focused pericellular proteolysis. Thus, our results support the hypothesis that integrins regulate UPAR distribution and that UPAR, in turn, contributes to the regulation of pericellular proteolysis. These findings provide impetus for the development of therapeutic agents that block leukocyte extravasation and tumor cell invasion by disrupting the linkage between integrins and uPAR (Xue et al. 1994, 1997).

Acknowledgements This work has been supported by NIH grants CA74120 (H.R.P.), CA-42246, and CA-39064 (R.F.T.) and a Merit Review grant of the Veteran's Administration (M.R.G.). D.K. was supported by the Howard Hughes Undergraduate Biological Sciences Educational Initiative.

\section{References}

Artym VV, Petty HR (2002) Molecular proximity of Kv1.3 voltage-gated potassium channels and $\beta 1$-integrins on the plasma membrane of melanoma cells: effects of cell adherence and channel blockers. J Gen Physiol 120:29-37

Babior BM (1978) Oxygen-dependent microbial killing by phagocytes. N Eng J Med 298:659-725

Bajpai A, Baker JB (1985) Cryptic urokinase binding sites on human foreskin fibroblasts. Biochem Biophys Res Com 133: 475-482

Bianchi E, Cohen RL, Thor AT, Todd RF, Mizukami IF, Lawrence DA, Ljung BM, Shuman MA, Smith HS (1994) The urokinase receptor is expressed in invasive breast cancer but not in normal breast tissue. Cancer Res 54:861-866

Blasi F (1993) Urokinase and urokinase receptor: a paracrine/ autocrine system regulating cell migration and invasiveness. Bioessays 15:105-111

Bohuslav J, Horejsi V, Hansmann C, Stockl J, Weidle UH, Majdic O, Bartke I, Knapp W, Stockinger H (1995) Urokinase plasminogen activator receptor, $\beta_{2}$-integrins, and src-kinases 
within a single receptor complex of human monocytes. J Exp Med 181:1381-1390

Campbell EJ, Campbell MA (1988) Pericellular proteolysis by neutrophils in the presence of proteinase inhibitors: effects of substrate opsonization. J Cell Biol 106:667-676

Cao D, Mizukami IF, Garni-Wagner BA, Kindzelskii AL, Todd III RF, Boxer LA, Petty HR (1995) Human urokinase-type plasminogen activator primes neutrophils for superoxide anion release: possible roles of complement receptor type 3 and calcium. J Immunol 154:1817-1829

Carmeliet P, Schoonjans L, Kieckens L, Ream B, Degan J, Bronson R, De Vos R, van den Oord JJ, Collen D, Mulligan RC (1994) Physiological consequences of loss of plasminogen activator gene function in mice. Nature 368:419-424

Coopman PJ, Thomas DM, Gehlen KR, Mueller SC (1996) Integrin $\alpha 3 \beta 1$ participates in the phagocytosis of extracellular matrix molecules by human breast cancer cells. Mol Biol Cell 7:1789-1804

Crowley CW, Cohen RL, Lucas BK, Liu G, Shuman MA, Levinson AD (1993) Prevention of metastasis by inhibition of the urokinase receptor. Proc Natl Acad Sci U S A 90:5021-5025

Estreicher A, Muhlhauser J, Carpentier J-L, Orci L, Vassalli JD (1990) The receptor for urokinase-type plasminogen activator polarizes expression of the protease to the leading edge of migrating monocytes and promotes degradation of enzyme inhibitor complexes. J Cell Biol 111:783-792

Farmer WH, Yuan Z (1991) A continuous fluorescent assay for measuring protease activity using natural protein substrate. Anal Biochem 197:347-352

Fazioli F, Blasi F (1994) Urokinase type plasminogen activator and its receptor: new targets for anti-metastatic therapy. Trends Pharmacol 15:25-29

Gadd SJ, Majdic O, Casinrerk W, Stockinger H, Maurer D, Eher R, Knapp W (1990) M5, a phosphoinositol-linked human myelomonocytic activation-associated antigen. Clin Exp Immunol 80:252-256

Granelli-Piperno A, Vassalli JD, Reich E (1977) Secretion of plasminogen activator by human polymorphonuclear leukocytes: modulation by glucocorticoids and other effectors. J Exp Med 146:1693-1706

Gyetko M, Webb A, Sitrin R (1988) Modulation of urokinase-type plasminogen activator and plasminogen activator inhibitor-2 expression by U937 mononuclear phagocytes. J Immunol 141:2693-2698

Gyetko MR, Todd III RF, Wilkinson CC, Sitrin RG (1994) The urokinase receptor is required for human monocyte chemotaxis in vitro. J Clin Invest 93:1380-1387

Hafeman DG, Seul M, Cliffe CM, McConnell HM (1984) Superoxide enhances photobleaching during cellular immune attack against fluorescent lipid monolayer membranes. Biochim Biophys Acta 772:20-28

Hearing VJ, Law LW, Corti A, Appella E, Blasi F (1988) Modulation of metastatic potential by cell surface urokinase of murine melanoma cells. Cancer Res 48:1270-1278

Herbert CA, Baker JB (1988) Linkage of extracellular plasminogen activator to the fibroblast cytoskeleton: colocalization of cell surface urokinase with vinculin. J Cell Biol 106:1241-1247

Hed J (1977) The extinction of fluorescence by crystal violet and its use to differentiate between attached and ingested microorganisms in phagocytosis. FEMS Microbiol Lett 1:357-361

Hormer KA, Beighton D (1990) Fluorometric determination of bacterial protease activity using fluorescein isothiocyanatelabeled proteins as substrates. Anal Biochem 191:133-137

Kindzelskii L, Laska ZO, Todd III RF, Petty HR (1996a) Urokinase-type plasminogen activator receptor reversibly dissociates from complement receptor type $3\left(\alpha_{\mathrm{M}} \beta_{2}\right)$ during neutrophil polarization. J Immunol 156:297-309

Kindzelskii AL, Ahmad I, Anderson D, Zhou MJ, Haugland RP, Mizukami I, Gyetko M, Todd III RF, Petty HR (1996b) Urokinase-type plasminogen activator receptors (uPAR) focus substrate proteolysis by neutrophils and tumor cells. FASEB J 10:A1333
Kindzelskii AL, Eszes MM, Todd III RF, Petty HR (1997) Proximity oscillations of complement receptor type 4 and urokinase receptors on migrating neutrophils. Biophys $\mathrm{J}$ 73:1777-1784

Kindzelskii AL, Zhou MJ, Haugland RP, Boxer LA, Petty HR (1998) Oscillatory pericellular proteolysis and oxidant deposition during neutrophil locomotion. Biophys J 74:90-97

Kirchheimer JC, Remold HG (1989) Endogenous receptor-bound urokinase mediates tissue invasion of human monocytes. J Immunol 143:2634-2639

Krause JC, Poo H, Xue W, Mayo-Bond L, Todd III RF, Petty HR (1994) Reconstitution of antibody-dependent phagocytosis in fibroblasts expressing both $\mathrm{Fc} \gamma$ receptor IIIB and the complement receptor type 3. J Immunol 153:1769-1777

Kummer JA, Avvink JJ, DeBoer JP, Roem D, Nieuwenhuya EJ, Kamp AM, Swaak TJG, Hack CE (1992) Analysis of intraarticular fibrinolytic pathways in patients with inflammatory and noninflammatory joint diseases. Arthritis Rheum 35:884-893

Lakowicz JR (1983) Principles of fluorescence spectroscopy, chap 9. Plenum, New York

Liou G, Campbell EJ (1996) Quantum proteolysis resulting from release of single granules by human neutrophils: a novel, nonoxidative mechanism of extracellular proteolytic activity. J Immunol 157:2624-2631

Min HY, Semnani R, Mizukami IF, Watt K, Todd III RF, Liu DY (1992) cDNA for Mo3, a monocyte activation antigen, encodes the human receptor for urokinase plasminogen activator. J Immunol 148:3636-3642

Mizukami IF, Vinjamuri SD, Trochelman RD, Todd III RF (1991a) A structural characterization of the Mo3 activation antigen expressed on the plasma membrane of human mononuclear phagocytes. J Immunol 144:1841-1848

Mizukami IF, Vinjamuri SD, Perini F, Liu DY, Todd III RF (1991b) Purification, biochemical characterization, and biosynthesis of the Mo3 activation antigen expressed on the plasma membrane of human mononuclear phagocytes. J Immunol 147:1331-1337

Mueller SC, Yeh Y, Chen WT (1992) Tyrosine phosphorylation of membrane proteins mediates cellular invasion by transformed cells. J Cell Biol 119:1309-1325

Mulligan RC, Berg P (1981) Selection for animal cells that express Escherichi coli gene coding for xanthine-guanine-phosphoribosyl-transferase. Proc Natl Acad Sci U S A 78:2072-2076

Nash AD, Uren S, Hawes CS, Boyle W (1989) Application of a novel immunization protocol to the production of monoclonal antibodies specific for macrophages in human placenta. Immunology 68:332-340

Ossowski L, Reich E (1983) Antibodies to plasminogen activator inhibit human tumor metastasis. Cell 35:611-619

Ossowski L, Russo-Payne H, Wilson EL (1991) Inhibition of urokinase-type plasminogen activator by antibodies: the effect on dissemination of a human tumor in nude mice. Cancer Res $51: 274-281$

Petty HR (1993) Molecular biology of membranes. Plenum, New York

Petty HR, Todd III RF (1996) Integrins as promiscuous signal transduction devices. Immunol Today 17:209-212

Ploug M, Ronne E, Behrendt N, Jensen AL, Blasi F, Dano K (1991) Cellular receptor for urokinase plasminogen activator carboxylterminal processing and membrane anchoring by glycosylphosphatidylinositol. J Biol Chem 266:1926-1933

Pollanen J, Saksela O, Salonen E-M, Andreasen P, Neilsen L, Dano K, Vaheri A (1987) Distinct localizations of urokinase-type plasminogen activator and its type 1 inhibitor under cultured human fibroblasts and sarcoma cells. J Cell Biol 104:10851096

Pollanen J, Hedman K, Nielsen LS, Dano K, Vaheri A (1988) Ultrastructural localization of plasma membrane-associated urokinase-type plasminogen activator at focal contacts. J Cell Biol 106:87-95 
Saksela O, Rifkin DB (1988) Cell-associated plasminogen activation: regulation and physiological functions. Annu Rev Cell Biol 4:93-126

Sameni M, Moin K, Sloane BF (2000) Imaging proteolysis by living human breast cancer cells. Neoplasia 2:496-504

Simon DI, Rao NK, Xu H, Wei Y, Majdic O, Ronne E, Kobzik L, Chapman HA (1996) Mac-1 (CD11b/CD18) and the urokinase receptor (CD87) form a functional unit on monocytic cells. Blood 88:3185-3194

Sitrin RG, Todd III RF, Petty HR, Brock TG, Shollenberger SB, Albrecht E, Gyetko MR (1996) The urokinase receptor (CD87) facilitates CD11b/CD18-mediated adhesion of human monocytes. J Clin Invest 97:1942-1951

Springer TA (1990) The sensation and regulation of interactions with the extracellular environment: the cell biology of lymphocyte adhesion receptors. Annu Rev Cell Biol 6:359-402

Szatrowski TP, Nathan CF (1991) Production of large amounts of hydrogen peroxide by human tumor cells. Cancer Res 51:794798

Takahashi K, Ikeo K, Gojobori T, Tanifuji M (1990) Local function of urokinase receptor at the adhesion contact sites of metastatic tumor cell. Thrombosis Res Suppl X:55-61

Todd RF III, Barnathan ES, Bohsulav J, Chapman HA, Cohen RL, Felez J, Howell A, Johnson JG, Knapp W, Kramer M, Miles LA, Nykjaer A, Ralfkilear E, Shchuren E (1995) CD87 Cluster workshop report. In: Schlossman SF, Boumsell L, Gilks W, Harlan JM, Kishimoto T, Morimoto C, Ritz J, Shaw S, Silverstein R, Springer T, Tedder TF, Todd RF (eds) Leucocyte typing V. Oxford University Press, Oxford, UK, pp 932-939

Twining SS (1984) Fluorescein isothiocyanate-labeled casein assay for proteolytic enzymes. Anal Biochem 143:30-34

Vassalli JD, Hamilton J, Reich E (1976) Macrophage plasminogen activator: modulation of enzyme production by anti-inflammatory steroids, mitotic inhibitors, and cyclic nucleotides. Cell $8: 271-281$

Wei Y, Lukashev M, Simon DI, Bodary SC, Rosenberg S, Doyle MV, Chapman HA (1996) Regulation of integrin function by urokinase receptor. Science 273:1551-1555

Xue W, Kindzelskii AL, Todd III RF, Petty HR (1994) Physical association of complement receptor type 3 and urokinasetype plasminogen activator receptor in neutrophil membranes. J Immunol 152:4630-4640

Xue W, Garni-Wagner BA, Todd III RF, Petty HR (1997) Urokinase-type plasminogen activator receptor is physically associated with $\beta 1$ and $\beta 3$ integrins of fibrosarcoma cells: dependence on extracellular matrix components. Cancer Res 57:1682-1689

Zar JH (1984) Biostatistical analysis. Prentice-Hall, Englewood Cliffs, NJ, pp 121-129 